\title{
Pengaruh Persepsi, Gender dan Tipe Kepribadian Mahasiswa Terhadap Pemilihan Karir Mahasiswa Akuntansi sebagai Akuntan Publik (Studi Kasus pada Mahasiswa Akuntansi Universitas Darma Persada)
}

\author{
Mohamad Ridwan Aditya* dan Ahmad Basid Hasibuan \\ Program Studi Akuntansi Fakultas Ekonomi, Universitas Darma Persada, Jakarta-Indonesia \\ *adityaridwan500@gmail.com danbasid_unsada@yahoo.co.id
}

How to cite (in APA style):

Aditya, M. R., \& Hasibuan, A. B. (2020). Pengaruh Persepsi, Gender dan Tipe Kepribadian Mahasiswa Terhadap Pemilihan Karir Mahasiswa Akuntansi sebagai Akuntan Publik (Studi Kasus pada Mahasiswa Akuntansi Universitas Darma Persada). Wacana Ekonomi (Jurnal Ekonomi, Bisnis dan Akuntansi). 19(1), pp.43-57. http:// dx.doi.org/10.22225/we.19.1.1579.43-57

\begin{abstract}
This research aims to analyze the influence of Perception, Gender and Accounting Student Personality Types toward Career Choice as a Public Accountant. This research was conducted by using surveys and questionnaires to students of accounting undergraduate programs who active and registered in the Accounting Department of the Economics Faculty, Darma Persada University in the study period 2018/2019 with a range of classes from 2014 to 2016. The sampling method in this study used a purposive sampling method. Total questionnaires disseminated were about 215 questionnaires with the number of questionnaires that can be used only as many as 200 questionnaires. This study utilizes primary data and secondary data to supporting research. The data analysis used is Multiple Linear Analysis with tested using SPSS 25 version. The results of the study based on multiple linear regression tests until the hypothesis test showed that the student perception, gender and personality variables had a positive and significant influence on career choice as public accounting by accounting students of Darma Persada University.
\end{abstract}

Keywords: Gender; myers-briggs type indicator; personality type; perception; career choice as public accountant

Abstrak

Penelitian ini bertujuan untuk menganalisis pengaruh Persepsi, Gender dan Tipe Kepribadian Mahasiswa Akuntansi terhadap Pemilihan Karir sebagai Akuntan Publik. Penelitian ini dilakukan dengan menggunakan survei dan penyebaran kuesioner kepada mahasiswa program sarjana akuntansi yang aktif dan terdaftar di Jurusan Akuntansi Fakultas Ekonomi Universitas Darma Persada pada periode 2018/2019 dengan rentang angkatan 2014 sampai dengan 2016. Metode pengambilan sampel pada penelitian ini menggunakan metode purposive sampling. Total kuesioner yang tersebar sebanyak 215 kuesioner dengan jumlah kuesioner yang dapat digunakan hanya sebanyak 200 kuesioner. Penelitian ini memanfaatkan data primer dan data sekunder dalam mendukung penelitian. Analisis data yang digunakan dalam penelitian ini adalah Analisis Linear Berganda yang diuji dengan menggunakan software SPSS versi 25. Hasil penelitian berdasarkan uji regresi linear berganda hingga uji hipotesis menunjukkan bahwa variabel persepsi mahasiswa, gender dan tipe kepribadian memiliki pengaruh yang positif dan signifikan terhadap variabel pemilihan karir sebagai akuntan publik mahasiswa akuntansi UNSADA.

Kata Kunci: Gender; myers-briggs type indicator; persepsi; pemilihan karir sebagai akuntan publik; tipe kepribadian

\section{PENDAHULUAN}

Sarjana ekonomi dari jurusan akuntansi dibatasi oleh pilihan karir yang disesuaikan terhadap pendidikan yang telah mereka tempuh pada pendidikan sarjana (Asmoro, Wijayanti, \& Suhendro, 2016; Yendrawati, 2007). Selepas menempuh pendidikan sarjana, mahasiswa ekonomi dari jurusan akuntansi setidaknya memiliki tiga alternatif pilihan sebagai langkah awal menentukan karir profesi yang akan digelutinya. Pertama adalah langsung terjun ke dalam dunia kerja setelah menempuh pendidikan sarjana. Kedua, seorang sarjana akuntansi dapat melanjutkan pendidikan pasca sarjana. Sedangkan yang ketiga adalah seorang sarjana akuntansi dapat menempuh Pendidikan Profesi Akuntan (PPA) jika ingin berprofesi sebagai akuntan (Candraning \& Muhammad, 2017). 
Teknologi, globalisasi, hubungan bisnis baru, dan lingkungan ekonomi multidisiplin telah mengubah profesi akuntansi (selanjutnya disebut Akuntan Publik) (Germanou, Hassall, \& Tournas, 2009; Zeff, 2003b, 2003a). Segala bentuk perubahan ini dapat memiliki pengaruh pada mereka yang memilih jurusan akuntansi serta faktor-faktor yang mempengaruhi pilihan mereka dari berbagai pekerjaan di lapangan (Holt, Burke-Smalley, \& Jones, 2017). Profesi audit sangat penting mengingat peran integral dan berkembang yang dimainkan oleh auditor baik internal maupun eksternal dalam memastikan deskripsi yang tepat dari posisi keuangan perusahaan dan kepatuhan terhadap peraturan yang berlaku. Memang, tantangan terus-menerus yang dihadapi profesi akuntansi terus menjadi perekrutan karyawan berkualitas tinggi yang cocok untuk pekerjaan di bidang akuntansi (Dalton, Buchheit, \& McMillan, 2014).

Bhumi Jariwala, asisten editor IFAC Global Knowledge Gateway, dalam tulisannya Exploring Artificial Intelligence and the Accountancy Profession: Opportunity, Threat, Both, Neither? berpendapat bahwa teknologi telah mengambil alih banyak pekerjaan akuntan sebelumnya seperti pengumpulan data akuntansi, pajak, dan audit, serta menyediakannya pada pengambil keputusan (Admin, 2016).

Pada tahun 2017 sensus ekonomi dari Badan Pusat Statistik (BPS) menunjukkan bahwa Indonesia memiliki total 26,7 juta perusahaan. Jika peneliti mengkategorikan data sesuai dengan skala bisnis, total 26,26 juta bisnis adalah pada skala Usaha Mikro, Kecil dan Menengah (UMKM) atau sama dengan $98,33 \%$. Lalu, 450.000 perusahaan adalah perusahaan menengah besar (Badan Pusat Statistik, 2017). Kenyataan tentang jumlah perusahaan yang ada di Indonesia dengan jumlah akuntan professional yang tersedia sangat memprihatinkan dimana pada tahun 2016, jumlah akuntan professional Indonesia tercatat hanya sekitar 28.110 akuntan professional (World Bank, 2016). Dengan jumlah ini, Indonesia berada jauh di bawah negara-negara anggota ASEAN lainnya seperti Thailand dengan 71,128 akuntan profesional, Singapura dengan 31.118 akuntan profesional, dan Malaysia dengan 32,990 akuntan profesional (A sean Federation of Accountant, 2016; World Bank Group, 2016).

Tabel 1

Akuntan yang Terdaftar dalam Asosiasi Profesi Akuntan di Negara-Negara ASEAN

\begin{tabular}{ccc}
\hline Negara Anggota & Asosiasi Profesi Akuntan & Total \\
\hline Thailand & FAP & 71.128 \\
Malaysia & MIA & 32.990 \\
Singapore & ISCA & 31.118 \\
Indonesia & IAI & 28.110 \\
Philippines & PICPAA & 19.573 \\
Vietnam & VAA & 9.800 \\
Myanmar & MICPA & 1.948 \\
Cambodia & KICPAA & 291 \\
Laos & LICPA & 102 \\
Brunei Darussalam & BICPA & 56 \\
& & $\mathbf{1 7 8 . 4 4 3}$
\end{tabular}

(Sumber: A sean Federation of A ccountant, 2016; World Bank Group, 2016)

Pada tahun 2017 sensus ekonomi dari Badan Pusat Statistik (BPS) menunjukkan bahwa Indonesia memiliki total 26,7 juta perusahaan. Jika peneliti mengkategorikan data sesuai dengan skala bisnis, total 26,26 juta bisnis adalah pada skala Usaha Mikro, Kecil dan Menengah (UMKM) atau sama dengan 98,33\%. Lalu, 450.000 perusahaan adalah perusahaan menengah besar (Badan Pusat Statistik, 2017). Kenyataan tentang jumlah perusahaan yang ada di Indonesia dengan jumlah akuntan professional yang tersedia sangat memprihatinkan dimana pada tahun 2016, jumlah akuntan professional Indonesia tercatat hanya sekitar 28.110 akuntan professional (World Bank, 2016). Dengan jumlah ini, Indonesia berada jauh di bawah negara-negara anggota ASEAN lainnya seperti Thailand dengan 71,128 akuntan profesional, Singapura dengan 31.118 akuntan profesional, dan Malaysia dengan 32,990 akuntan profesional (Asean Federation of Accountant, 2016; World Bank Group, 2016). 
Tabel 2

Jumlah Akuntan Vs Jumlah Penduduk Negara-Negara di ASEAN

\begin{tabular}{|l|l|r|r|r|}
\hline No & Negara & $\begin{array}{r}\text { Jumlah } \\
\text { Akuntan } \\
\text { (Jan'15)* }\end{array}$ & $\begin{array}{r}\text { Jumlah } \\
\text { Penduduk } \\
\text { dalam } \\
\text { Ribuan } \\
\text { (Des'14) }\end{array}$ & $\begin{array}{r}\text { Jumlah } \\
\text { Akuntan per } \\
1.000 .000 \\
\text { Penduduk }\end{array}$ \\
\hline 1. & Brunei & 56 & 406,2 & 138 \\
\hline 2. & Cambodia & 291 & $14.962,6$ & 19 \\
\hline 3. & Indonesia & 24.587 & $248.818,1$ & 99 \\
\hline 4. & Lao PDR & 176 & $6.644,0$ & 26 \\
\hline 5. & Malaysia & 31.815 & $29.948,0$ & 1.062 \\
\hline 6. & Myanmar & 1.948 & $61.568,0$ & 32 \\
\hline 7. & Philippines & 18.214 & $99.384,5$ & 183 \\
\hline 8. & Singapore & 28.891 & $5.399,2$ & 5.351 \\
\hline 9. & Thailand & 62.739 & $68.251,0$ & 919 \\
\hline 10. & Vietnam & 9.800 & $89.708,9$ & 109 \\
\hline & Total & 178.517 & $625.090,5$ & \\
\hline
\end{tabular}

(Sumber : IAI \& www.asean.org)

Berdasarkan Tabel 2 yang di dapat dari Asean Federation of Accountant, 2016; World Bank Group, 2016 jumlah akuntan yang terdaftar di asosiasi profesi akuntan di Indonesia, masih terbilang sedikit. Jumlah ini jika dibandingkan dengan jumlah penduduk Indonesia yang saat ini kira-kira 250 juta jiwa, memberikan perbandingan yang tidak seberapa antara jumlah akuntan dengan jumlah penduduk, hal ini terbukti masih perlu peningkatan atas akuntan dan akuntan publik yang beregistrasi negara. Hal ini didukung juga oleh Survei dari Pusat Pembinaan Profesi Keuangan (PPPK), yang menunjukkan bahwa pertumbuhan profesi akuntan publik dalam dekade empat tahun terakhir dimulai dari tahun 2015 sebesar 1.121 orang, 2016 sebesar 1.233 orang, 2017 sebesar 1.354 orang dan 2018 sebesar 1.408 orang. Penurunan tersebut menstimulasikan bahwa hampir 94\% kemungkinan beberapa pekerjaan akuntansi dan audit akan digantikan oleh tenaga otomatis berbasis teknologi Artificial Intelligent atau komputer dalam 20 tahun ke depan (Dikutip dari Peran Akuntan Profesional Dalam Revolusi Industri 4.0, Ikatan Akuntan Indonesia).

Sayangnya stereotip para akuntan, persepsi dan sikap terhadap profesi akuntansi belum berubah. Kuantitas dan kualitas lulusan akuntansi yang bekerja sebagai profesional dalam akuntansi publik telah menurun dalam beberapa tahun terakhir (Mauldin, Crain, \& Mounce, 2000; Sawarjuwono \& Kalanjati, 2013; Smith, 2005; Tan \& Laswad, 2009) di Indonesia. Profesi Akuntansi telah kehilangan kemampuannya untuk menarik perhatian mahasiswa berpotensi sehingga menimbulkan kekhawatiran tentang masa depan dari profesi akuntansi itu sendiri (Marriott \& Marriott, 2003; "Peer Review Standards Interpretations," 2019).

\section{TINJAUAN PUSTAKA}

\section{Teori Pengharapan (Expectancy Theory)}

Konsep dari pemilihan profesi ini berhubungan dengan teori motivasi yakni teori pengharapan (expectancy theory). Motivasi merupakan konsep yang menguraikan tentang kekuatan-kekuatan individu untuk memulai dan mengarahkan perilakunya terhadap pekerjaan tertentu (James, Ivanvevich, \& Donnely Jr, 1997; Setiyani, 2005). Motivasi adalah aktivitas perilaku yang bekerja dalam usaha memenuhi kebutuhan-kebutuhan yang diinginkan (Robbins \& Couler, 2016). Teori pengharapan merupakan salah satu dari teori motivasi, definisi dari teori pengharapan adalah kekuatan dari kecenderungan untuk bertindak dengan cara tertentu bergantung pada kekuatan pengharapan bahwa tindakan itu akan diikuti oleh output tertentu dan tergantung pada daya tarik 
output tersebut bagi individu itu. Secara singkat, kunci dari teori pengharapan adalah pemahaman sasaran individu dan keterkaitan antara upaya dan kinerja, antara kinerja dan imbalan. Oleh karena itu pemilihan karir mahasiswa akuntansi ditentukan oleh pengharapan akan karir yang akan mereka pilih apakah karir tersebut dianggap dapat memenuhi kebutuhan individu mereka dan apakah karir tersebut mempunyai daya tarik bagi mereka. Oleh karena itu pemilihan karir mahasiswa akuntansi ditentukan oleh pengharapan akan karir yang akan mereka dapatkan saat menekuni karir tersebut, apakah karir tersebut dapat memenuhi kebutuhan yang mereka inginkan dan memberikan daya tarik secara khusus kepada individu tersebut.

\section{Teori Perilaku Terencana ( Theory of Planned Behavior )}

Menurut Ajzen dan Fishbein (1991), sikap dan kepribadian seseorang berpengaruh terhadap perilaku tertentu hanya jika secara tidak langsung dipengaruhi oleh beberapa faktor yang berkaitan erat dengan perilaku, dapat digambarkan sebagai berikut:

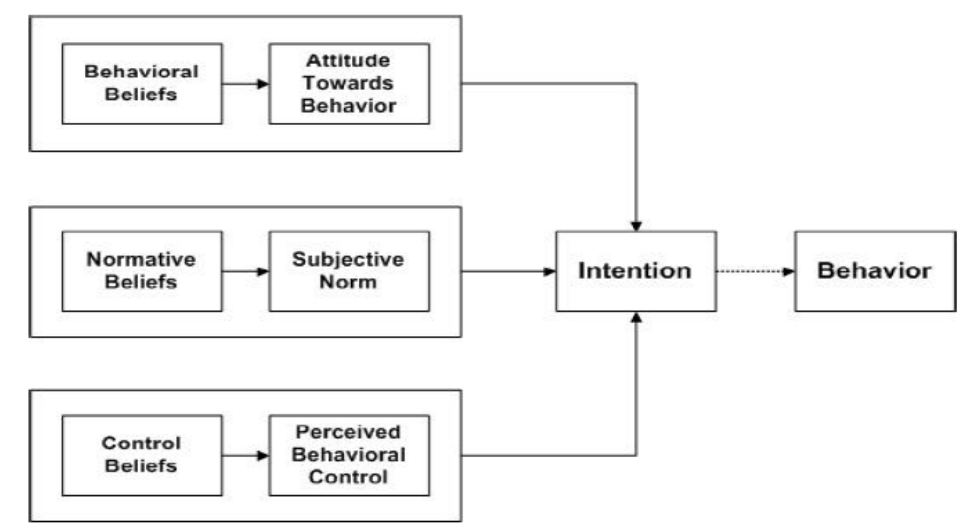

Figure 1

Theory Planned Behavior (Ajzen, 1991)

Target perilaku yang diinginkan harus didefinisikan berdasarkan 4 (empat) elemen yaitu; Target, Action, Context dan Time (TACT) (Ajzen, 1991). Target perilaku yang diinginkan memiliki prisip kesesuaian, kekhususan maupun keadaan umum seperti dijelaskan berikut ini :

\section{Compatibility (Kesesuaian)}

Walaupun keempat elemen TACT dari perilaku tersebut dapat didefinisikan, namun sangat penting untuk diteliti atau diamati tentang prinsip keserasian/kesesuaian (principle of compatibility) dari seluruh variabel yang membangun teori perilaku terencana ini (sikap, norma subyektif, kontrol terhadap perilaku, dan maksud / tujuan) untuk didefinisikan juga kedalam empat elemen TACT. Selain itu, juga harus dinilai atau diperkirakan maksud dan tujuan dalam menjalankan perilaku tersebut.

\section{Specificity dan Generality (Kekhususan dan keadaan umum)}

Elemen TACT merupakan contoh yang cukup spesifik, tetapi tidak tertutup kemungkinan untuk meningkatkan ke arah kondisi yang lebih umum untuk masing-masing elemen dengan melakukan agregasi atau penyatuan. Melihat perilaku hanya dalam satu peristiwa / kesempatan biasanya terlalu terbatas untuk menjadi nilai praktis yang lebih. Dengan cara yang sama, dalam beberapa kasus, konteks yang lebih spesifik mungkin tidak menarik. Elemen konteks yang lebih umum dapat dimuat dengan merekam seberapa sering perilaku tersebut dilakukan pada semua konteks yang relevan. Argumen serupa juga dapat dilontarkan untuk elemen tindakan (Action). Namun demikian, harus digambarkan secara eksplisit perilaku yang dimaksud kepada para responden. Elemen TACT mendefinisikan perilaku dalam tingkat yang teoritis, responden mendefinisikan perilaku dalam konsep laten (tidak langsung). Sekali dapat didefinisikan, indikator nyata dari perilaku tersebut diperoleh baik dari observasi langsung maupun melalui laporan pribadi. Sikap, norma subyektif, kontrol terhadap perilaku (perceived behavioral control) dan maksud / tujuan (intention) biasanya ditentukan secara langsung berdasarkan prosedur standar penghitungan (standard scaling procedures). Ketika melakukan penghitungan, indicator / ukuran yang digunakan 
Wacana Ekonomi (Jurnal Ekonomi Bisnis dan Akuntansi), 19 (1) 2020, 47

harus sesuai dengan perilaku dalam elemen tindakan, target, tindakan, konteks, dan waktu (TACT).

Persepsi

Persepsi adalah merupakan proses kognitif yang memungkinkan kita menginterpretasikan dan memahami sekitar kita (Kreitner \& Kinicki, 2014). Dikatakan pula sebagai proses menginterpretasikan suatu lingkungan. Orang harus mengenal objek untuk berinteraksi sepenuhnya dengan lingkungan mereka. Persepsi adalah proses menerima informasi membuat pengertian tentang dunia di sekitar kita. Hal tersebut memerlukan pertimbangan informasi mana yang perlu diperhatikan, bagaimana mengkategorikan informasi, dan bagaimana menginterpretasikannya dalam kerangka kerja pengetahuan kita yang telah ada (McShane \& Von Glinow, 2010).

\section{Gender}

Istilah jenis kelamin dengan gender memiliki arti yang berbeda, yaitu "jenis kelamin" adalah atribut-atribut fisiologis dan anatomis yang membedakan antara laki-laki dan perempuan, sedangkan "gender" dipakai untuk menunjukan perbedaan-perbedaan antara laki-laki dan perempuan yang di pelajari (Wade \& Tavris, 2007). Gender merupakan bagian dari system sosial, seperti status sosial, usia, dan etnis, itu adalah faktor penting dalam menentukan peran, hak, tanggung jawab dan hubungan antara pria dan wanita. Penampilan, sikap, kepribadian tanggung jawab adalah perilaku yang akan membentuk gender.

Women's Studies Encyclopedia, menjelaskan gender sebagai suatu konsep kultural yang berupaya membuat perbedaan dalam hal peran, perilaku, mentalitas, dan karakteristik emosional antara laki-laki dan perempuan yang berkembang dalam masyarakat. Gender sebagai perbedaan yang tampak pada laki - laki dan perempuan apabila dilihat dari nilai dan tingkah laku (Santrock, 2011). Gender merupakan merupakan aspek hubungan sosial yang dikaitkan dengan diferensiasi seksual pada manusia dan sudah melekat pada laki-laki maupun perempuan yang dikonstruksi secara sosial maupun kultural.

\section{Kepribadian}

Kepribadian adalah merupakan hasil dari Heredity dan Environtment (Robbins, 2017). Dia juga berpendapat bahwa situation mempengaruhi Heredity dan Environment pada Kepribadian. Sementara itu, life experience atau pengalaman hidup, terutama pada awal kehidupan juga membentuk sifat kepribadian seseorang (McShane \& Von Glinow, 2010). Kepribadian atau personality didefinisikan sebagai kombinasi karakteristik fisik dan mental yang stabil yang memberikan identitas individualnya (Kreitner \& Kinicki, 2014). Karakteristik atau ciri atau sifat ini termasuk bagaimana orang melihat, berpikir, bertindak dan merasakan, yang merupakan produk interaksi genetik dan pengaruh lingkungan.

\section{Myers-Briggs Type Indicator (MBTI)}

Myers-Briggs Type Indicator (MBTI) adalah instrumen pengukuran yang digunakan untuk mengukur preferensi kepribadian individu. Myers-Briggs Type Indicator (MBTI) dikembangkan oleh Katharine Cook Briggs dan anaknya, Isabel Briggs Myers pada tahun 1962 berdasarkan teori tipe kepribadian Carl Gustav Jung di tahun 1921. Mengadopsi teori Jung, Myers-Briggs Type Indicator (MBTI) mengukur fungsi kepribadian yang sudah ada dalam tiga dimensi yang sudah ada. Namun terdapat tambahan fungsi baru yaitu judging dan perceiving yang diletakkan dalam dimensi attitude.

Dalam Myers-Briggs Type Indicator (MBTI) empat dimensi kepribadian dijabarkan lebih mendetail dan terdiri dari cara individu berinteraksi dengan lingkungan sekitarnya $E$ (extraversion) atau I (introversion), cara individu menelaah situasi dan mengumpulkan informasi S (sensing) atau $\mathrm{N}$ (intuition), cara individu membuat keputusan atau kesimpulan $\mathrm{T}$ (thinking) atau $\mathrm{F}$ (feeling) dan cara individu menghadapi dunia luar $\mathrm{J}$ (judging) atau $\mathrm{P}$ (perceiving). Perlu diketahui masing-masing individu memiliki kedelapan fungsi kepribadian dalam dirinya. Klasifikasi Myers-Briggs Type Indicator (MBTI) hanya menunjukkan preferensi dari kepribadian-kepribadian tersebut. Rangkaian dari empat aspek yang telah disebutkan di atas membentuk kombinasi tipe preferensi kepribadian. Terdapat total enam belas kombinasi tipe preferensi kepribadian. Kombinasi tersebut dapat dijelaskan pada table berikut : 
Tabel 3

Tipe Kepribadian Myers-Briggs Type Indicator (MBTI)

\begin{tabular}{|c|c|c|c|}
\hline ESTJ & ENTJ & ESFJ & ENFJ \\
\hline $\begin{array}{l}\text { Logis, sistematis, } \\
\text { kritis dan analitikal }\end{array}$ & $\begin{array}{c}\text { Sistematis, sesuai visi, } \\
\text { konseptual dan } \\
\text { terorganisir } \\
\end{array}$ & $\begin{array}{c}\text { Faktual, kooperatif dan } \\
\text { serba praktis }\end{array}$ & $\begin{array}{l}\text { Iba, loyal, imajinatif, } \\
\text { mendukung dan suka } \\
\text { keragaman }\end{array}$ \\
\hline ESTP & ENTP & ESFP & ENFP \\
\hline $\begin{array}{l}\text { Pengamat, aktif, } \\
\text { rasional dan tegas }\end{array}$ & $\begin{array}{c}\text { Kreatif, imajinatif, } \\
\text { teoretis, analitis, } \\
\text { rasional dan interogatif }\end{array}$ & $\begin{array}{l}\text { Pengamat, spesifik, } \\
\text { simpatik dan idealis }\end{array}$ & $\begin{array}{l}\text { Ingin tahu, kreatif, penuh } \\
\text { semangat, bersahabat dan } \\
\text { kooperatif }\end{array}$ \\
\hline ISTJ & INTJ & ISFJ & INFJ \\
\hline $\begin{array}{l}\text { Tegas, bijak, } \\
\text { praktis, objektif } \\
\text { dan logis }\end{array}$ & $\begin{array}{l}\text { Berwawasan, jangka } \\
\text { panjang, rasional dan } \\
\text { objektif }\end{array}$ & $\begin{array}{l}\text { Tangguh, praktis, } \\
\text { kooperatif dan } \\
\text { sensitive }\end{array}$ & $\begin{array}{l}\text { Berwawasan, simbolis, } \\
\text { idealis, komitmen dan iba }\end{array}$ \\
\hline ISTP & INTP & ISFP & INFP \\
\hline $\begin{array}{l}\text { Objektif, logis, } \\
\text { pragmatis dan } \\
\text { faktual }\end{array}$ & $\begin{array}{l}\text { Logis, ingin tahu, } \\
\text { objektif, berwawasan } \\
\text { dan kontemplatif }\end{array}$ & $\begin{array}{l}\text { Penuh kepercayaan, } \\
\text { ramah, sensitiif, } \\
\text { pengamat, praktis dan } \\
\text { tangguh }\end{array}$ & $\begin{array}{l}\text { Sensitif, peduli, idealis, } \\
\text { ingin tahu, kreatif dan } \\
\text { visioner }\end{array}$ \\
\hline \multicolumn{4}{|c|}{ Petunjuk Istilah } \\
\hline $\begin{array}{l}\text { E: Extroversion } \\
\text { I : Introversion }\end{array}$ & $\begin{array}{c}\text { S : Sensing } \\
\mathrm{N}: \text { Intuition }\end{array}$ & $\begin{array}{c}\text { T: Thinking } \\
\mathrm{F}: \text { Feeling }\end{array}$ & $\begin{array}{c}\text { J : Judging } \\
\text { P : Perceiving }\end{array}$ \\
\hline
\end{tabular}

Sumber : www.myersbriggs.org

Hipotesis

Pengaruh persepsi terhadap pemilihan karir sebagai akuntan publik

Semakin baik persepsi mahasiwa akuntansi mengenai karir dan profesi auditor, maka semakin tinggi minat untuk menjadi seorang akuntan publik. Persepsi merupakan proses pengaturan dan penerjemahan informasi sensorik oleh otak. Persepsi dapat dikatakan merupakan salah satu aspek psikologis yang penting bagi manusia dalam merespon kehadiran berbagai aspek dan gejala di sekitarnya (Wade \& Tavris, 2007). Persepsi adalah suatu proses dengn mana individual mengorganisir dan menginterpretasikan tanggapan kesan mereka dengan maksud memberi makna pada lingkungan mereka (Robbins, 2017). Tapi ada yang kita rasakan dapat berbeda secara substansial dari realitas ojektif. Hasil Penelitian (Germanou et al., 2009; Mbawuni, 2015; Pramitasari, Sukoharsono, \& Djamhuri, 2017) menyatakan bahwa persepsi berpengaruh terhadap pemilihan karir sebagai akuntan publik oleh mahasiswa akuntansi.

\section{Pengaruh gender terhadap pemilihan karir sebagai akuntan publik}

Kultur masyarakat pada era sebelum kartini yang melarang wanita untuk bekerja pada saat ini sudah sangat jauh dari persepsi masyarakat, wanita sekarang sudah dianggap memiliki peran dan berkarya dalam seluruh aspek kehidupan sosial, dalam bidang akuntansi seorang wanita dapat menekuni berbagai bidang profesi akuntan yang ada baik akuntan publik, akuntan perusahaan, akuntan pemerintah dan akuntan pendidik. Gender adalah pembedaan laki-laki dan perempuan dilihat dari konstruksi sosial budaya (Showalter, 1989). Namun ada beberapa karakter dasar yang tidak dapat disamakan antara pria dan wanita yaitu emosi, dan pola pemikiran yang cukup berbeda antara pria dan wanita (Santrock, 2011). Terdapat pengaruh dan perbedaan signifikan pengaruh gender terhadap faktor-faktor yang mempengaruhi mahasiswa dalam memilih profesi akuntan publik dengan profesi non akuntan publik (Law, 2010; Mbawuni, 2015).

\section{Pengaruh kesesuaian tipe kepribadian terhadap pemilihan karir sebagai akuntan publik}

Personalitas merupakan salah satu determinan yang potensial terhadap pelaku individu saat berhadapan dengan situasi/ kondisi tertentu. Hal ini membuktikan bahwa personalitas berpengaruh terhadap perilaku seseorang (Rahayu, 2003). Personalitas merupakan salah satu determinan yang potensial terhadap perilaku individu saat berhadapan dengan kondisi tertentu (Chan, 2012). Personalitas berarti karakteristik psikologi dari dalam yang menentukan dan merefleksikan bagaimana seseorang merespon lingkungannya. Dalam pemilihan karir sebagai akuntan hasil penelitian (Aprilyan \& Laksito, 2011) menyatakan bahwa variabel personalitas berpengaruh terhadap 
pemilihan karir sebagai akuntan. Hasil penelitian ini didukung oleh hasil penelitian dan (Felton, Buhr, \& Northey, 1994; Wheeler, 1983) menemukan bahwa kepribadian mahasiswa akuntansi yang memiliki minat untuk berprofesi sebagai akuntan publik memiliki kepribadian yang khas stereotip Akuntan Publik. Hubungan tipe kepribadian dan karir ini pun dibuktikan dengan hasil bahwa karyawan yang berprofesi sebagai Akuntan Publik merasa nyaman dengan pekerjaannya, dalam hal ini orang-orang yang tertarik dengan profesi akuntan publik adalah orang-orang yang merasa cocok dengan stereotip citra dari akuntan publik yang ada (Chan, 2012; Rahayu, 2003; Suyono, 2014). Tipe kepribadian yang diusulkan sebagai Akuntan adalah seseorang yang memiliki tipe kepribadian ESTJ dan ISTJ. Penelitian ini menggunakan MBTI (Myers-Briggs Type Indicator) sebagai alat ukur tipe kepribadian dengan pertimbangan bahwa tes MBTI tidak hanya mampu mengukur tipe kepribadian seseorang, tetapi juga mampu merekomendasikan jurusan atau karir yang sesuai dengan tipe kepribadian tersebut.

\section{METODE}

Dalam penelitian ini, ruang lingkup penelitian terbatas pada lingkungan Fakultas Ekonomi Universitas Darma Persada. Hal ini dikarenakan pembatasan ruang lingkup akan mempermudah penulis dalam mengumpulkan data/sampel. Ada pun sampel dari penelitian ini terbatas pada mahasiswa Jurusan Akuntansi Fakultas Ekonomi Universitas Darma Persada yang telah atau sedang menjalankan pendidikan selama paling sedikit lima (5) semester masa perkuliahan dan telah mengambil mata kuliah Auditing 1, Auditing 2, Perpajakan $1 \&$ 2, Akuntansi Keuangan Lanjutan, Akuntansi Sektor Publik dan Akuntansi Syariah. Tujuan dari spesifikasi ini adalah agar mahasiswa akuntansi yang menjadi responden dalam penelitian ini setidaknya memiliki referensi pilihan profesi yang diminati untuk menjadi pilihan karirnya di masa depan. Dalam hal ini responden termasuk tahun angkatan 2014, 2015 dan 2016. Teknik pengambilan sampel dilakukan secara sampling bertujuan (purposive sampling) dimana sampel dipilih atas kriteria-kriteria tertentu.

Data primer diperoleh melalui kegiatan pengumpulan data dari individu dengan memberikan informasi ketika diwawancara, diberikan kuesioner atau diobservasi. Dalam penelitian ini data diperoleh dengan melakukan survei secara langsung ke sumber data. Riset dilakukan secara langsung pada Mahasiswa Jurusan Akuntansi Universitas Darma Persada yang dijadikan sebagai objek penelitian. Kegiatan ini dilakukan agar penulis dapat mengumpulkan data yang berhubungan langsung dengan permasalahan yang dikemukakan penulis yang kemudian dianalisa. Penelitian dilakukan dengan cara observasi dan penyebaran kuesioner.

Data sekunder (secondary data) dalam penelitian ini mengacu pada informasi yang dikumpulkan dari sumber-sumber yang telah ada. Data sekunder ini merupakan data yang sifatnya mendukung keperluan data primer seperti buku-buku, literatur dan bacaan yang berkaitan dan menunjang penelitian ini. Data sekunder pada penelitian ini berupa jurnal hasil dari penelitian terdahulu, buku referensi, dan data di situs-situs internet yang akurat (IAI.org.id, worldbankgroup.org, Kementerian Keuangan Indonesia, ASEAN.org, dan sebagainya) yang mendukung dan berkaitan dengan faktor persepsi, gender dan tipe personalitas mahasiswa terhadap pemilihan karir di bidang akuntan publik.

\section{Definisi Operasional Variabel dan Pengukurannya}

Variabel dependen yang diteliti yaitu pemilihan karir sebagai akuntan publik. Pemilihan karir sebagai akuntan publik yaitu minat praktisi individual atau anggota Kantor Akuntan Publik yang memberikan jasa auditing profesional kepada klien. Pemilihan karir menjadi akuntan publik diukur dengan indicator seperti, motivasi, kebutuhan fisiologis, kebutuhan rasa aman, kebutuhan sosial. kebutuhan akan penghargaan, kebutuhan aktualisasi diri. Variabel Pemilihan karir sebagai akuntan publik diukur menggunakan skala Likert dengan rentang nilai 1 sampai dengan 5.

Dalam penelitian ini terdapat tiga variabel independen yang diteliti yaitu persepsi (X1), gender (X2), dan tipe kepribadian (X3). Persepsi dalam pemilihan karir akuntan publik oleh mahasiswa akuntansi meliputi indikator seperti, proses perkuliahan, pengetahuan dan manfaat berkarir sebagai akuntan publik, pelatihan sertifikasi CPA, kemampuan analitis dan kemampuan interpersonal individu. Variabel Persepsi diukur menggunakan skala Likert dengan rentang nilai 1 sampai dengan 5. Gender didefinisikan sebagai konsep kultural yang berupaya membuat pembedaan dalam hal peran, perilaku, mentalitas dan karakteristik emosional antara laki-laki dan perempuan atau dalam hal 
pemilihan karir. Variabel Gender diukur menggunakan skala Nominal. Skala Nominal adalah skala pengukuran yang menyatakan kategori, kelompok atau klasifikasi dari construct yang diukur dalam bentuk variabel (Indriantoro \& Supomo, 2009). Skala Nominal ini dinyatakan dengan angka: 1 (lakilaki) dan 2 (perempuan).

Tipe kepribadian mahasiswa yang dimaksudkan dalam penelitian ini adalah kesesuaian tipe kepribadian mahasiswa akuntansi yang diukur menggunakan Myers Briggs Type Indicator (MBTI) test. MBTI Test terdiri dari 20 pernyataan. Setiap pernyataan, terdiri dari dua pilihan yang bertolak belakang. Mahasiswa akan diminta untuk memilih salah satu dari dua pernyataan tersebut. Setiap pilihan pernyataan akan mengarahkan kecenderungan tipe kepribadian mahasiswa (apakah lebih cenderung pada tipe kepribadian introvert daripada ekstrovert, apakah lebih cenderung pada tipe kepribadian sensing daripada intuition, apakah lebih cenderung pada tipe thingking daripada feeling, atau apakah lebih cenderung pada tipe kepribadian judging daripada perceiving). Untuk dapat dikatagorikan tipe kepribadian introvert (I), sensing (S), thinking (T), judging (J), skor minimal adalah 5 skor untuk masing-masing dimensi tipe kepribadian. Jika skor masing-masing dimensi tipe kepribadian kurang dari 5 skor, maka dapat dikatakan tipe kepribadian responden lebih cenderung pada ekstrovert $(\mathrm{E})$, intuition $(\mathrm{N})$, feeling $(\mathrm{F})$, perceiving $(\mathrm{P})$. Apabila hasil menunjukkan bahwa mahasiswa tersebut bukan merupakan salah satu dari gabungan tipe kepribadian ESTJ atau ISTJ, maka dapat dikatakan tipe kepribadian mahasiswa yang bersangkutan tidak sesuai dengan jurusan akuntansi (Mudrika, 2011). Mahasiswa dengan tipe kepribadian yang sesuai dengan jurusan akuntansi, akan diberikan nilai 1, sementara mahasiswa dengan tipe kepribadian yang tidak sesuai dengan jurusan akuntansi, akan diberikan nilai 0 .

\section{Teknik Analisis Data}

Penelitian ini menggunakan metode analisis data Regresi Linier Berganda dengan bantuan software stastistik IBM SPSS 25.0 ver. Analisis regresi linier berganda pada penelitian ini bertujuan untuk menguji tingkat signifikansi pengaruh persepsi, gender dan tipe personalitas terhadap pemilihan karir mahasiswa di bidang akuntan publik. Model Persamaan regresi tersebut sebagai berikut :

Keterangan :

$$
\mathbf{P K}=\mathbf{a}+\mathbf{B}_{1} \text { PERS }+\mathbf{B}_{2} \text { GEN }+ \text { B }_{3} \text { PSON }+\mathbf{e}
$$

$\begin{array}{ll}\mathrm{PK} & : \text { Pemilihan Karir Mahasiswa di Bidang Akuntan Publik } \\ \mathrm{a} & : \text { Konstanta } \\ \mathrm{B}_{1}-\mathrm{B}_{3} & : \text { Koefisien regresi dari masing-masing variabel independen } \\ \text { PERS } & : \text { Persepsi Mahasiswa } \\ \mathrm{GEN} & : \text { Gender/Jenis Kelamin } \\ \text { PSON } & : \text { Personality/Tipe Kepribadian } \\ \mathrm{E} & : \text { Error term }\end{array}$

Besarnya konstanta tercermin dari dalam a dan besarnya koefisien regresi dari masing-masing variabel independen ditunjukan dengan $\mathrm{B}_{1}, \mathrm{~B}_{2}$ dan $\mathrm{B}_{3}$.

\section{HASIL DAN PEMBAHASAN}

Karakteristik responden dapat membantu peneliti dalam mengelompokkan jumlah responden berdasarkan karakteristik-karakteristik tertentu. Sehingga penelitian ini menjadi terukur dan terarah dalam mencapai tujuan penelitian. Pada bagian ini akan dibagi berdasarkan demografi, tahun angkatan, semester dan mata kuliah yang telah atau sedang diikuti.

Jumlah responden laki-laki terdiri dari 42 atau setara $21 \%$ dari jumlah sampel keseluruhan, sedangkan perempuan sejumlah 158 orang atau setara $79 \%$ dari jumlah responden keseluruhan. Jumlah responden mahasiswa berjenis kelamin perempuan mendominasi hingga 58\% diatas persentase responden laki-laki.

Dari 200 responden mahasiswa yang mengisi kuesioner, terbagi atas tiga tahun angkatan perkuliahan. Tahun angkatan 2014 berjumlah 34 mahasiswa atau setara 17\% dari jumlah responden mahasiswa, tahun angkatan 2015 berjumlah 85 mahasiswa atau setara 42,5\% dari jumlah responden mahasiswa dan tahun angkatan 2016 berjumlah 81 mahasiswa atau setara 40,5\% dari jumlah 
responden mahasiswa.

Berdasarkan semester yang telah ditempuh oleh mahasiswa, diketahui bahwa jumlah responden dari semester 8 (delapan) paling banyak diantara semester lainnya yaitu sebanyak 85 mahasiswa atau setara $42,5 \%$ dari total responden, kemudian terdapat semester 6 (enam) dengan jumlah responden sebanyak 83 mahasiswa atau setara dengan $41,5 \%$ dari jumlah responden keseluruhan. Mahasiswa yang sedang menjalankan semester diatas semester 8 (delapan) atau dalam kuesioner disebut sebagai semester Lainnya berjumlah 32 mahasiswa yang setara dengan $16 \%$ dari total responden keseluruhan.

Keseluruhan responden yang menjadi sampel dalam penelitian ini telah atau sedang mengikuti minimal perkuliahan Auditing 1. Total responden yang telah atau sedang menempuh perkuliahan Auditing 2 adalah sebanyak 188 responden atau setara hanya $94 \%$ dari total responden, perkuliahan Perpajakan 1 \& 2 sebanyak 192 responden atau setara 96\% dari total responden, perkuliahan Akuntansi Keuangan Lanjutan sebanyak 184 responden atau setara 92\% dari total responden, perkuliahan Akuntansi Sektor Publik sebanyak 185 atau 92,5\% dari total responden dan di angka terendah perkuliahan Akuntansi Syariah sebanyak 175 responden atau hanya setara 87,5\% dari total responden.

Dalam hasil statistika, preferensi kepribadian Myers-Briggs Type Indicator (MBTI) terbagi atas delapan fungsi dimana peneliti menjabarkan baris sesuai dengan dimensi dikotominya. Dari dimensi perilaku, mahasiswa Akuntansi UNSADA sebagian besar berada pada Ekstroversion (Ekspresif; suka menyatakan yang ada di pikiran) dengan 61,5\%. Dalam hal ini menandakan bahwa sebagian besar mahasiswa Akuntansi UNSADA memiliki fokus perhatian lebih untuk menghabiskan waktunya di dunia luar dengan keterlibatannya dalam acara dan berbagai macam kegiatan sehingga mayoritas juga suka ketika bersosialisasi dan berada di sekitar banyak orang. Dari dimensi penerimaan dan pengolahan informasi, dengan besaran $75 \%$, lebih menjurus pada kepribadian Sensing (pengamat yang baik) dimana dalam melakukan segala sesuatu selalu bertahap dan terstruktur sesuai dengan prosedur. Dari dimensi pembuatan keputusan sebanyak 68,5\% mahasiswa Akuntansi UNSADA memiliki kecenderungan yaitu Thinking (Skeptis; Tegas) dimana individu dengan kepribadian ini mendasarkan prinsip dan kebenaran dalam membuat keputusan, terlepas dari situasi spesifik yang terlibat. Selain itu individu dengan kepribadian ini cenderung menganalisa pro dan kontra serta konsisten dan logis ketika membuat keputusan.

Pada dimensi orientasi, sebagian mahasiswa Akuntansi UNSADA lebih menjurus pada jadwal yang terarah dibandingkan dengan suatu hal yang fleksibel, dibuktikan pada fungsi Judging (Perencana) dengan persentase sebesar 65,5\%. Dari hasil tes yang sudah dilakukan pada 200 responden mahasiswa akuntansi Universitas Darma Persada didapatkan hasil tipe kepribadian MBTI dimana secara jelas dapat digambarkan pada grafik dibawah ini:

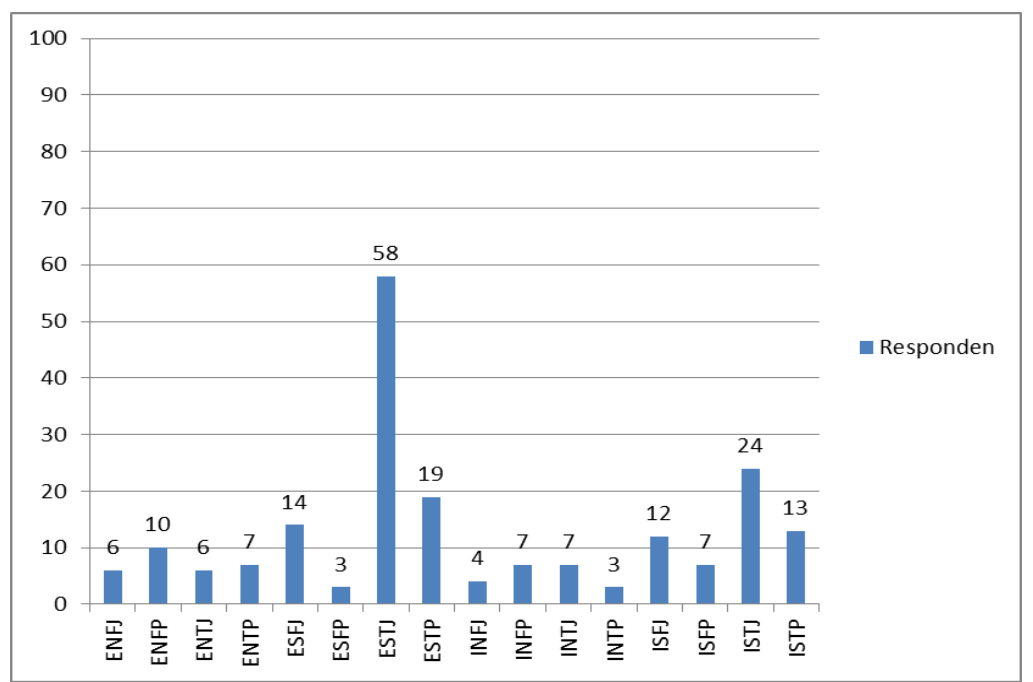

Figure 2

Grafik Jumlah dan Persentase Tipe Kepribadian Mahasiswa Akuntansi UNSADA (Grafik Kombinasi 16 Kepribadian)

Sumber : Data yang diolah, 2019 
Berdasarkan 16 kombinasi, preferensi kepribadian Extroversion, Sensing, Thinking dan Judging menjadi preferensi kepribadian dominan pada Mahasiswa Akuntansi UNSADA, hal ini menandakan bahwa terdapat mayoritas Mahasiswa Akuntansi UNSADA yang mempunyai sifat logis, sistematis, kritis, objektif dan analitikal serta konservatif yang apabila dikaitkan dengan variabel terikat yaitu Pemilihan Karir sebagai Akuntan Publik, tipe kepribadian mayoritas mahasiswa Akuntansi UNSADA sesuai dengan profesi Akuntan Publik/Auditor.

\section{Uji Reliabilitas}

Tabel 4

Hasil Uji Reliabilitas

\begin{tabular}{ccc}
\hline No & Variabel & Chonbach's Alpha \\
\hline 1 & Persepsi $\left(\mathrm{X}_{1}\right)$ & 0,742 \\
2 & Gender $\left(\mathrm{X}_{2}\right)$ & 0,776 \\
3 & Tipe Kepribadian $\left(\mathrm{X}_{3}\right)$ & 0,860 \\
4 & Pemilihan Karir Akuntan Publik $(\mathrm{Y})$ & 0,742 \\
\hline
\end{tabular}

Sumber : Data diolah dengan SPSS 25

Suatu variabel dikatakan reliabel jika memberikan nilai cronbach's alpha $>0,70$ (Ghozali, 2018). Dari table diatas, dapat diartikan bahwa semua variabel dalam penelitian ini memiliki nilai Cronbach's Alpha $(\alpha)$ yang tinggi sehingga semua variabel dinyatakan reliabel. Tingginya tingkat nilai Cronbach's Alpha $(\alpha)$ memberikan arti bahwa variabel persepsi, gender dan tipe kepribadian memiliki pengaruh yang tinggi pada hasil jawaban responden terhadap variabel pemilihan karir sebagai akuntan publik dalam penelitian ini.

\section{Uji Validitas}

Uji validitas digunakan untuk mengukur sah atau valid tidaknya suatu kuesioner (Ghozali, 2018). Suatu kuesioner dikatakan valid jika pertanyaan mampu mengungkapkan sesuatu yang akan diukur oleh kuesioner tersebut. Pengujian validitas dapat dilakukan dengan melihat nilai Corrected Item-Total Correlation. Jika nilai rhitung lebih besar dari rtabel dan nilainya positif maka pernyataan tersebut dikatakan valid.

Tabel 5

Hasil Uji Validitas X1

\begin{tabular}{ccccc}
\hline & $\begin{array}{c}\text { Scale Mean if Item } \\
\text { Deleted }\end{array}$ & $\begin{array}{c}\text { Item-Total Statistics } \\
\text { Scale Variance if } \\
\text { Item Deleted }\end{array}$ & $\begin{array}{c}\text { Corrected Item-Total } \\
\text { Correlation }\end{array}$ & $\begin{array}{c}\text { Cronbach's Alpha if } \\
\text { Item Deleted }\end{array}$ \\
\hline P1 & 121.27 & 152.741 & .396 & .726 \\
P2 & 121.47 & 151.466 & .369 & .725 \\
P3 & 121.31 & 152.907 & .374 & .727 \\
P4 & 121.65 & 149.084 & .505 & .720 \\
P5 & 121.56 & 148.710 & .564 & .718 \\
P6 & 121.58 & 149.783 & .446 & .721 \\
P7 & 121.51 & 150.814 & .405 & .724 \\
P8 & 121.76 & 147.231 & .616 & .718 \\
P9 & 121.58 & 148.607 & .557 & .720 \\
P10 & 121.87 & 148.556 & .458 & .723 \\
P11 & 121.58 & 151.150 & .442 & .719 \\
P12 & 121.58 & 149.029 & .511 & .722 \\
P13 & 121.58 & 149.883 & .441 & .714 \\
P14 & 122.19 & 146.463 & .573 & .720 \\
P15 & 122.11 & 149.059 & .456 & .720 \\
P16 & 122.40 & 148.009 & .425 & .816 \\
\hline
\end{tabular}

Sumber : Data diolah dengan SPSS 25 
Wacana Ekonomi (Jurnal Ekonomi Bisnis dan Akuntansi), 19 (1) 2020, 53

\begin{tabular}{ccccc}
\hline \multicolumn{5}{c}{ Tabel 6 } \\
\multicolumn{5}{c}{ Hasil Uji Validitas X2 } \\
& $\begin{array}{c}\text { Scale Mean if } \\
\text { Item Deleted }\end{array}$ & $\begin{array}{c}\text { Item-Total Statistics } \\
\text { Scale Variance if } \\
\text { Item Deleted }\end{array}$ & $\begin{array}{c}\text { Corrected Item- } \\
\text { Total Correlation }\end{array}$ & $\begin{array}{c}\text { Cronbach's Alpha if Item } \\
\text { Deleted }\end{array}$ \\
\hline G1 & 70.20 & 224.955 & .685 & .746 \\
G2 & 69.61 & 227.466 & .639 & .750 \\
G3 & 69.83 & 225.860 & .706 & .747 \\
G4 & 70.23 & 229.964 & .560 & .754 \\
G5 & 70.00 & 222.854 & .742 & .743 \\
G6 & 69.52 & 227.115 & .665 & .749 \\
G7 & 69.61 & 227.696 & .695 & .749 \\
G8 & 69.71 & 226.541 & .694 & .748 \\
G9 & 69.90 & 226.758 & .704 & .748 \\
G10 & 69.75 & 231.940 & .636 & .755 \\
G11 & 69.74 & 230.374 & .715 & .752 \\
JUMLAH & 36.58 & 62.256 & 1.000 & .900 \\
\hline
\end{tabular}

Uji validitas Variabel X3 (Tipe Kepribadian) dengan Instrumen Myers-Briggs Type Indicator (MBTI) sesungguhnya tidak lagi diuji pada penelitian berikutnya karena karakteristik psikometrik yang baik dan memadai dari Myers-Briggs Type Indicator menurut Wheeler (2001). Dalam Wheeler (2001), validitas Myers-Briggs Type Indicator (MBTI) mencapai 0.7, oleh karena itu sebagai instrumen penelitian dapat dikatakan valid.

Tabel 7

Hasil Uji Validitas Y

\begin{tabular}{lcccc}
\hline & $\begin{array}{c}\text { Scale Mean if Item } \\
\text { Deleted }\end{array}$ & $\begin{array}{c}\text { Scale Variance } \\
\text { if Item Deleted }\end{array}$ & $\begin{array}{c}\text { Corrected Item- } \\
\text { Total Correlation }\end{array}$ & $\begin{array}{c}\text { Cronbach's Alpha } \\
\text { if Item Deleted }\end{array}$ \\
\hline PK1 & 132.69 & 234.026 & .613 & .733 \\
PK2 & 132.75 & 234.932 & .546 & .734 \\
PK3 & 132.81 & 235.635 & .579 & .735 \\
PK4 & 132.91 & 236.127 & .545 & .735 \\
PK5 & 132.82 & 233.676 & .598 & .732 \\
PK6 & 132.88 & 236.599 & .542 & .736 \\
PK7 & 133.20 & 232.935 & .601 & .732 \\
PK8 & 132.61 & 237.676 & .538 & .737 \\
PK9 & 132.39 & 236.701 & .547 & .736 \\
PK10 & 132.41 & 237.781 & .576 & .737 \\
PK11 & 132.28 & 238.353 & .515 & .738 \\
PK12 & 132.41 & 236.555 & .581 & .736 \\
PK13 & 132.48 & 238.824 & .434 & .739 \\
PK14 & 132.69 & 240.096 & .374 & .741 \\
PK15 & 132.84 & 234.782 & .629 & .733 \\
PK16 & 132.62 & 236.769 & .565 & .736 \\
PK17 & 132.73 & 237.163 & .507 & .737 \\
PK18 & 132.73 & 236.361 & .588 & .735 \\
JU13 & 62.422 & 1.000 & .884 \\
\hline
\end{tabular}

Sumber : Data diolah dengan SPSS 25

\section{Uji Asumsi Klasik}

Pengujian asumsi klasik terhadap model regresi menyatakan bahwa model regresi telah memenuhi uji normalitas, uji multikolinearitas dan uji heteroskedastisitas.

\section{Analisis Regresi Linier Berganda}


Wacana Ekonomi (Jurnal Ekonomi Bisnis dan Akuntansi), 19 (1) 2020, 54

\begin{tabular}{|c|c|c|c|c|c|c|}
\hline \multicolumn{7}{|c|}{$\begin{array}{c}\text { Tabel } 8 \\
\text { Hasil Regresi Linier Berganda }\end{array}$} \\
\hline & \multirow{2}{*}{ Model } & \multicolumn{2}{|c|}{$\begin{array}{l}\text { Unstandardized } \\
\text { Coefficients }\end{array}$} & \multirow{2}{*}{$\begin{array}{c}\text { Standardized } \\
\text { Coefficients } \\
\text { Beta }\end{array}$} & \multirow{2}{*}{$\mathrm{T}$} & \multirow{2}{*}{ Sig. } \\
\hline & & B & $\begin{array}{l}\text { Std. } \\
\text { Error }\end{array}$ & & & \\
\hline \multirow{5}{*}{1} & (Constant) & 15.879 & 4.309 & & 3.685 & .000 \\
\hline & Persepsi & .685 & .071 & .547 & 9.606 & .000 \\
\hline & Gender & .221 & .057 & .221 & 3.862 & .000 \\
\hline & Tipe Kepribadian & 1.796 & .927 & .106 & 1.937 & .044 \\
\hline & a. I & ent Var & Pemilih & ir Akuntan Pul & & \\
\hline
\end{tabular}

Sumber : Data diolah dengan SPSS 25

Berdasarkan hasil pengolahan data pada tabel diatas maka diperoleh persamaan regresi linier sebagai berikut:

$\mathrm{PK}=\mathrm{a}+\mathrm{B} 1 \mathrm{PERS}+\mathrm{B} 2 \mathrm{GEN}+\mathrm{B} 3 \mathrm{PSON}+\mathrm{e}$

$\mathrm{PK}=15,879+0,685 \mathrm{PERS}+0,221 \mathrm{GEN}+1,796 \mathrm{PSON}+\mathrm{e}$ berikut:

Hasil dari persamaan regresi linier berganda dan simpulan hipotesis dapat dijelaskan sebagai

\section{Pengaruh Persepsi (XI) terhadap pemilihan karir sebagai akuntan publik (Y)}

Hipotesis pertama yang menyatakan bahwa persepsi berpengaruh terhadap pemilihan karir sebagai akuntan publik. Hasil analisis uji t pada tabel di atas untuk variabel persepsi diperoleh nilai $t_{\text {hitung }}$ sebesar 9,606 $>t_{\text {tabel }}(1,6527)$ dengan nilai signifikan sebesar 0,000 berarti lebih kecil dari 0,05 maka H0 ditolak dan Ha dapat diterima. Sedangkan berdasarkan persamaan regresi terlihat bahwa koefisien variabel persepsi adalah positif, hal ini berarti meningkatnya persepsi responden bahwa persepsi dapat meningkatkan pemilihan karir akuntan publik. Dengan demikian dapat diartikan bahwa variabel persepsi berpengaruh positif dan signifikan terhadap pemilihan karir sebagai akuntan publik.

\section{Pengaruh Gender (X2) terhadap pemilihan karir sebagai akuntan publik (Y)}

Hipotesis kedua yang menyatakan bahwa gender berpengaruh terhadap pemilihan karir sebagai akuntan publik. Hasil analisis uji t pada tabel di atas untuk variabel gender diperoleh, nilai $t_{\text {hitung }}$ sebesar 3,862 $>t_{\text {tabel }}(1,6527)$ dengan nilai signifikan sebesar 0,000 berarti lebih kecil dari 0,05 maka $\mathrm{HO}$ ditolak dan Ha dapat diterima. Sedangkan berdasarkan persamaan regresi terlihat bahwa koefisien variabel gender adalah positif, hal ini berarti meningkatnya persepsi responden bahwa gender dapat meningkatkan pemilihan karir sebagai akuntan publik. Dengan demikian dapat diartikan bahwa variabel gender berpengaruh positif dan signifikan terhadap pemilihan karir sebagai akuntan publik.

\section{Pengaruh Tipe kepribadian (X3) terhadap pemilihan karir sebagai akuntan publik (Y)}

Hipotesis ketiga yang menyatakan bahwa tipe kepribadian berpengaruh terhadap pemilihan karir sebagai akuntan publik. Hasil analisis uji t pada tabel di atas untuk variabel pengalaman diperoleh nilai $t_{\text {hitung }}$ sebesar $1,937>t_{\text {tabel }}(1,6527)$ dengan nilai signifikan sebesar 0,044 berarti lebih kecil dari 0,05 maka H0 ditolak dan Ha dapat diterima. Sedangkan berdasarkan persamaan regresi terlihat bahwa koefisien variabel tipe kepribadian adalah positif, hal ini berarti meningkatnya persepsi responden tentang tipe kepribadian dapat meningkatkan pemilihan karir sebagai akuntan publik. Dengan demikian dapat diartikan bahwa variabel tipe kepribadian berpengaruh positif dan signifikan terhadap pemilihan karir sebagai akuntan publik.

\section{SIMPULAN}

Penelitian ini bertujuan untuk mengetahui dan mengukur seberapa besar pengaruh persepsi, gender dan tipe kepribadian terhadap pemilihan karir sebagai akuntan publik pada mahasiswa akuntansi UNSADA yang telah memiliki pengalaman atau minimal pengetahuan mengenai akuntan publik/auditor. Objek yang diteliti adalah mahasiswa jurusan akuntansi yang sedang atau telah menempuh minimal mata kuliah Auditing 1 pada angkatan 2014, 2015 dan 2016 dimana mahasiswa 
yang dijadikan objek penelitian sebanyak 200 mahasiswa seperti yang telah diuraikan sangat jelas pada bab sebelumnya. Berdasarkan hasil pengujian hipotesis, maka hasil penelitian dapat disimpulkan sebagai berikut: Persepsi berpengaruh positif dan signifikan terhadap pemilihan karir sebagai akuntan publik. Hal ini menunjukkan bahwa tanggapan atau persepsi mahasiswa mengenai karir sebagai akuntan publik juga dapat memberi pengaruh terhadap ketepatan pemilihan karir para mahasiswa lulusan akuntansi di bidang akuntan publik. Gender memiliki pengaruh positif dan signifikan terhadap pemilihan karir sebagai akuntan publik. Penelitian ini menyatakan bahwa peluang bagi kaum perempuan untuk menjadi akuntan publik semakin menurun dibandingkan laki-laki dikarenakan terdapat beberapa pertimbangan baik dari individual maupun perusahaan sebagai pemberi kerja. Tipe kepribadian mahasiswa akuntansi memiliki pengaruh positif dan signifikan terhadap pemilihan karir sebagai akuntan publik. Dengan diperolehnya skor yang besar untuk tipe kepribadian ESTJ dan ISTJ dapat disimpulkan bahwa, seseorang yang memiliki preferensi dan tipe kepribadian khususnya sensing, thinking dan Judjing memiliki pengaruh terhadap minat mahasiswa akuntansi UNSADA dalam berkarir menjadi akuntan publik.

Mahasiswa akuntansi hendaknya terus meningkatkan wawasan dan pengetahuannya mengenai profesi auditor atau akuntan publik, tidak hanya terbatas pada pengetahuan yang telah diperoleh lewat perkuliahan di kampus tetapi, harus mampu memperbanyak melalui kegiatan pelatihan, seminar atau diskusi publik. Hal ini penting untuk membentuk persepsi yang lebih tepat dan akurat mengenai profesi akuntan publik. Mahasiswa akuntansi dengan gender perempuan hendaknya terus meningkatkan potensi diri yang dimiliki di bidang akuntansi tidak hanya terbatas pada akuntan publik namun ruang lingkup akuntansi yang lainnya seperti perpajakan, akuntansi pemerintahan, akuntansi pendidik dan sebagainya. Setelah mengetahui bagaimana preferensi tipe kepribadian yang dimiliki, mahasiswa akuntansi hendaknya memahami dan mengasah keunikan psikologis yang dimiliki sebagai bentuk persiapan diri untuk menuju ke dunia kerja yang tentunya sangat berbeda dengan dunia pelajar atau perkuliahan. Dalam hal ini kaitannya adalah karir di bidang akuntan.

\section{DAFTAR PUSTAKA}

Admin, S. (2016). 2040: Menerawang Masa Depan Seorang Akuntan. Retrieved from https://spafebui.com/2040-menerawang-masa-depan-seorang-akuntan/

Ajzen, I. (1991). The theory of planned behavior. Organizational Behavior and Human Decision Processes, 50 (2), 179-211. Retrieved from https://doi.org/10.1016/0749-5978(91)90020-T

Aprilyan, L. A., \& Laksito, H. (2011). Faktor-Faktor Yang Mempengaruhi Mahasiswa Akuntansi Dalam Pemilihan Karir Menjadi Akuntan Publik (Studi Empiris pada Mahasiswa Akuntansi UNDIP dan Mahasiswa Akuntansi UNIKA). Diponegoro University Institutional Repository. Retrieved from http://eprints.undip.ac.id/26837/

Asmoro, T. K. W., Wijayanti, A., \& Suhendro. (2016). Faktor-Faktor Yang Mempengaruhi Mahasiswa Akuntansi Dalam Pemilihan Karir Sebagai Akuntan Publik. Jurnal Akuntansi ManajeriaL, l(1). Retrieved from http://journal.uta45jakarta.ac.id/index.php/JAM/article/view/734

Candraning, C., \& Muhammad, R. (2017). Faktor-faktor yang mempengaruhi minat mahasiswa bekerja di lembaga keuangan syariah. Jurnal Ekonomi \& Keuangan Islam, 3(2), 90-98. Retrieved from https:// doi.org/10.20885/jeki.vol3.iss2.art5

Chan, A. S. (2012). Analisis Faktor-Faktor yang Mempengaruhi Pemilihan Karir Menjadi Akuntan Publik Oleh Mahasiswa Jurusan Akuntansi. Jurnal Ilmiah Mahasiswa Akuntansi, 1(1), 53-58. Retrieved from http://journal.wima.ac.id/index.php/JIMA/article/download/13/11

Dalton, D. W., Buchheit, S., \& McMillan, J. J. (2014). Audit and Tax Career Paths in Public Accounting: An Analysis of Student and Professional Perceptions. Accounting Horizons, 28(2), 213-231. Retrieved from https://doi.org/10.2308/acch-50665

Felton, S., Buhr, N., \& Northey, M. (1994). Factors influencing the businessstudent's choice of a career in chartered accountancy. Issues in Accounting Education, 9(1), 131-141. Retrieved from https:// www.econbiz.de/Record/factors-influencing-the-business-student-s-choice-of-a-career-in-chartered- 
accountancy-felton-sandra/10006409119

Germanou, E., Hassall, T., \& Tournas, Y. (2009). Students' perceptions of accounting profession: work value approach. Asian Review of Accounting, 17(2), 136-148. Retrieved from https:// doi.org/10.1108/13217340910975279

Ghozali, I. (2018). Aplikasi Analisis Multivariate dengan Program IBM SPSS 25 Update PLS Regresi. Semarang: Badan Penerbit Universitas Diponegoro.

Holt, T., Burke-Smalley, L. A., \& Jones, C. (2017). An Empirical Investigation of Student Career Interests in Auditing Using the Big Five Model of Personality. Advances in Accounting Education: Teaching and Curriculum, 20, 1-31. Retrieved from https://doi.org/10.1108/S1085-462220170000020002

Indriantoro, N., \& Supomo, B. (2009). Metodologi Penelitian Bisnis. Yogyakarta: Badan Penerbit Fakultas Ekonomi Universitas Gadjah Mada.

James, G. L., Ivanvevich, J. M., \& Donnely Jr, J. H. (1997). Manajemen, Proses dan Struktur, ahli bahasa Agus Dharma. Jakarta: Erlangga.

Kreitner, R., \& Kinicki, A. (2014). Perilaku Organisasi. Edisi 9. Buku 1. Jakarta: Salemba Empat.

Law, P. K. (2010). A theory of reasoned action model of accounting students' career choice in public accounting practices in the post-Enron. Journal of Applied Accounting Research, 11(1), 58-73. Retrieved from https://doi.org/10.1108/09675421011050036

Marriott, P., \& Marriott, N. (2003). Are we turning them on? A longitudinal study of undergraduate accounting students' attitudes towards accounting as a profession. Accounting Education, 12(2), 113-133. Retrieved from https://doi.org/10.1080/0963928032000091738

Mauldin, S., Crain, J. L., \& Mounce, P. H. (2000). The Accounting Principles Instructor's Influence on Students' Decision to Major in Accounting. Journal of Education for Business, 75(3). Retrieved from https://doi.org/10.1080/08832320009599005

Mbawuni, J. (2015). Examining Students' Feelings and Perceptions of Accounting Profession in a Developing Country: The Role of Gender and Student Category. International Education Studies, 8(6), 9-23. Retrieved from https://files.eric.ed.gov/fulltext/EJ1067768.pdf

McShane, S. L., \& Von Glinow, M. A. (2010). Organizational Behavior: Emerging Knowledge and Practice for The Real World (5th ed.). New York: The McGraw-Hill Companies.

Mudrika, N. (2011). Membaca Kepribadian Menggunakan Tes MBTI (Myer Briggs Type Indicator). Retrieved from https://nafismudrika.wordpress.com/2011/02/18/membaca-kepribadian-menggunakan-tes-mbtimyer-briggs-type-indicator/

Peer Review Standards Interpretations. (2019). Retrieved from https:/www.aicpa.org/Research/Standards/ PeerReview/DownloadableDocuments/PeerReviewStandardsInterpretations.pdf

Pramitasari, A. P., Sukoharsono, E. G., \& Djamhuri, A. (2017). The Influence of Auditor's Personality Types, Experience, Ethics, and Gender on Fraud Detection Capability: Study of Big Four Public Accounting Firm in Indonesia. Imperial Journal of Interdisciplinary Research (IJR), 3(7), 640-653. Retrieved from https://pdfs.semanticscholar.org/cee3/e59139e228140c87aba7d82be7a1abcb2d5d.pdf? ga=2.109151746.660578245.1581036141-1145283201.1581036141

Rahayu, S. (2003). Persepsi mahasiswa akuntansi mengenai faktor-faktor yang mempengaruhi pemilihan karir. UPT Perpustakaan Universitas Sebelas Maret. Retrieved from https://digilib.uns.ac.id/dokumen/ detail/964/Persepsi-mahasiswa-akuntansi-mengenai-faktor-faktor-yang-mempengaruhi-pemilihankarir

Robbins, S. P. (2017). Prinsip-Prinsip Perilaku Organisasi: Edisi Kelima. Jakarta: Erlangga.

Robbins, S. P., \& Couler, M. (2016). Manajemen edisi 13 jilid 2. Jakarta: Erlangga.

Santrock, J. W. (2011). Life-Span Development, Perkembangan Masa Hidup Jilid 1 (edisi kelima). Jakarta: 


\section{Erlangga.}

Sawarjuwono, T., \& Kalanjati, D. (2013). Menumbuhkan Cinta Profesi Akuntan Publik bagi Generasi Penerus. Jurnal Akuntansi Dan Bisnis, 13(1). Retrieved from http://dx.doi.org/10.20961/jab.v13i1.132

Setiyani, R. (2005). Faktor-Faktor Yang Membedakan Mahasiswa Akuntansi Dalam Memilih Profesi Sebagai Akuntan Publik dan Non Akuntan Publik. (Studi Empiris Pada Mahasiswa Akuntansi Perguruan Tinggi Negeri di Pulau Jawa). Program Pascasarjana Universitas Diponegoro. Retrieved from http://eprints.undip.ac.id/10225/

Showalter, E. (1989). Towards a Feminist Poetics" in Contemporary Literary Criticism. Davis, Robert Con (ed.). London: Longman.

Smith, G. (2005). Reversing the decreasing trend of students majoring in accounting. Managerial Auditing Journal, 20(9), 936-944. Retrieved from https://doi.org/10.1108/02686900510625280

Suyono, N. A. (2014). Analisis Faktor-Faktor Yang Mempengaruhi Pemilihan Karir Sebagai Akuntan Publik (Studi Empiris Pada Mahasiswa Akuntansi Unsiq). Jurnal Penelitian Dan Pengabdian Kepada Masyarakat, 1(2), 69-83. Retrieved from https://doi.org/10.32699/ppkm.v1i2.235

Tan, L. M., \& Laswad, F. (2009). Understanding Students' Choice of Academic Majors: A Longitudinal Analysis. Accounting Education, 18(3), 233-253. Retrieved from https:// doi.org/10.1080/09639280802009108

Wade, C., \& Tavris, C. (2007). Psikologi Edisi Kesembilan Jilid 2. Jakarta: Erlangga.

Wheeler, K. G. (1983). Perceptions of labor market variables by college students in business, education, and psychology. Journal of Vocational Behavior, 22(1), 1-11. Retrieved from https:// doi.org/10.1016/0001-8791(83)90002-7

Yendrawati, R. (2007). Persepsi Mahasiswa dan Mahasiswi Akuntansi Mengenai Faktor-faktor yang Mempengaruhi Pemilihan Karir sebagai Akuntan. Fenomena: Jurnal Ilmu Ilmu Sosial Humaniora, 5 (2). Retrieved from https://journal.uii.ac.id/index.php/Fenomena/article/view/1107

Zeff, S. A. (2003a). How the U.S. Accounting Profession GotWhere It Is Today: Part II. Accounting Horizons, 17(4), 267-286. Retrieved from http://www.ruf.rice.edu/ sazeff/PDF/Horizons, Part II \%28print\% 29.pdf

Zeff, S. A. (2003b). How the U.S. Accounting ProfessionGot Where It Is Today: Part I. Accounting Horizons, 17(3), 189-205. Retrieved from http://www.ruf.rice.edu/ sazeff/PDF/Horizons, Part I (print).pdf 